\title{
Hungarian Expectations and Jewish Self-Definitions, 1840-1914
}

In the first half of the nineteenth century, adopting in large part the ideological rationale previously put forth by German Jewry, ${ }^{1}$ Jews in Hungary also engaged in the task of redefining Judaism and what it meant to be a Jew. In 1842, two years before his death, Aaron Chorin, the pioneer Reform rabbi, was probably the first Hungarian Jew to formulate in a concise, slogan-like form the dogma professed by Jews aspiring to integrate into the majority society while retaining their-reconceptualized-Jewish identity: "With the scattering of the Israelites, their nationality has perished. And so there is no Israelite nation, rather, Jews are merely a religious community, like all other denominations. Just like the Catholic or the Protestant, [...] the Jew too is a Hungarian in Hungary, a German in Germany, and a Frenchman in France."2

This dogma, which constituted the fundamental principle presiding over the emancipation of the Jews, would be proclaimed by the Hungarian political and cultural elite until the introduction of the numerus clausus in 1920, and repeated again and again by integrationist Jews at least until the Holocaust. Yet, from the 1890s onwards, alongside the constant assertion that Jews were solely a religious body, Neolog intellectuals (rabbis, journalists and scholars writing in Neolog Jewish periodicals) spoke more and more frequently of the Jewish "people," the Jewish népfaj [approximatively Volksstamm], and even the Jewish race, faj. The use of these terms remained often unconscious, casual, unsystematic. Frequently, however, they were used in a way clearly at odds with the definition of Jewishness reduced to a matter of faith.

This flagrant contradiction leads to the question of the respective dynamics of external pressure and internal developments in the course of modern Jewish history. This is an old debate in Jewish historiography, and I would tend to be among those who insist on the importance of external pressure. After all, nothing indicates its weight more clearly than the fact that the core tenet of the liberal ideology of Jewish integration, the assertion that Jews were nothing else than a

1 Michael Silber, “The Historical Experience of German Jewry and its Impact on Haskalah and Reform in Hungary," in Toward Modernity: The European Jewish Model, ed. Jacob Katz (New Brunswick and Oxford: Transaction Books, 1987), 127.

2 "Gutachten des Ober-Rabbiners Herrn Chorin," in Rabbinische Gutachten über die Verträglichkeit der freien Forschung mit dem Rabbineramte (Breslau: Druck von Leopold Freund, 1842), 31. 
community of faith, was a blatantly false description of the realities of Jewish life, a description in which it is hard to believe that those who professed it had ever regarded it as true without any reservations.

I do not claim that the confessionalisation of Judaism, and more generally, the moderate version of Reform Judaism developed in Hungary, were only driven by the ambition to make Judaism acceptable to Gentile society, or the necessity to satisfy external expectations. They certainly stemmed in part from the desire to make Judaism compelling to modernized Jews, to offer a self-definition allowing them to harmonize their evolving Jewish and developing Hungarian identities. Nevertheless, one thing seems to me quite certain: there was little chance that Jews who considered legal emancipation and social acceptance as a priority would advance self-definitions incompatible with Hungarians' own vision of the legitimate form of continued Jewish existence.

How, then, to explain that by the end of the nineteenth century, Neolog intellectuals enlarged the definition of Jewishness by speaking of the Jewish "people," of the Jewish népfaj, and even of the Jewish "race"? Was it then that Hungarian expectations were in fact less coercive than is usually thought? Or did that reflect a change in the priorities of Neolog Jewish intellectuals? If we assume that the pressure of external expectations inevitably influenced and partly determined modern Jewish self-definitions, the first question that should be answered is what exactly the Hungarian political and cultural elite was expecting from Jews. Which definitions of Judaism and Jewishness became inadmissible, and which ones remained more or less permissible? Only by answering these questions can we assess how much room for ideological maneuver Jews theoretically had. In the first part of my paper, I will try to show that because of the contradictions in the discourse of the Hungarian elite, their room for maneuver remained rather large, certainly larger than is usually thought. In the second part of my article, I examine how Neolog intellectuals used this opportunity, and for what purpose.

\section{Gentile Expectations}

In Hungary, in contrast with the Austrian hereditary lands, but very much like in Germany or France, the denationalization of the Jews was their entry ticket to emancipation. It was all the more so in Hungary since at the time of the Hungarian Vormärz (1830-1848), when the emerging liberal camp elaborated its version of the modern nation-state, the Hungarian Kingdom was a country where non-Hungarian ethnic groups, some of which themselves had set out on the 
road to national awakening, comprised roughly sixty percent of the population. ${ }^{3}$ According to the concept of "political nation" that would prevail until the collapse of the Dual Monarchy, no other ethnic group besides Hungarians (and to a lesser degree Croatians) could legitimately pretend to constitute a nation. In 1839, in its Dietal instructions, that is the written orders to its elected representatives to the Diet, the county of Pest asked for the bestowal of civil rights to the Jews, "given that the Hungarian nation does not consider Jews as a separate nation of the country but only as different citizens." 4

Struggling to adapt the concept of the nation-state to the most ethnically diverse country in Europe, Hungarian liberal nationalism necessarily accepted that within the Hungarian nation there might exist a variety of ethnic groups. ${ }^{5}$ But could the Jews qualify as a "people" in the sense of an ethnic community? The answer is both yes and no. On the one hand, in the parliamentary debates and the press of the 1840s, Hungarians often called Jews a "people” or a népfaj. After all, it would have been difficult to deny their common origins, culture and traditions. On the other hand, they were not recognized as a real "people" since they did not have their own language. Or more precisely, since the first thing expected from Jews was to adopt the Hungarian language in order to increase the number of Hungarians, the recognition of Jewish ethnicity, unlike in the case of the Romanians, Slovaks, or Germans, did not imply recognition of the legitimate survival of the Yiddish language, all the less so since it was not considered to be a real language, but only a "jargon." This explains why, in a book published in 1847, the famous statistician Elek Fényes defined the Jews as a népfaj, then declared a few pages later that they did not constitute a "people" since they did not possess a language of their own. ${ }^{6}$

Yet, for Lajos Kossuth, the leader of the liberal nationalists, in the current state of the Jewish religion, which he considered to be not merely a religion but rather a

3 Tamás Dobszay and Zoltán Fónagy, “A rendi társadalom utolsó évtizedei” [The Last Decades of Feudal Society], in Magyarország története a 19. században [The History of Hungary in the $19^{\text {th }}$ Century], ed. András Gergely (Budapest: Osiris Kiadó, 2003), 81.; Endre Arató, A magyarországi nemzetiségek nemzeti ideológiája [The National Ideology of Hungarian Nationalities] (Budapest: Akadémiai Kiadó, 1983).

4 Sándor Büchler, A zsidók története Budapesten a legrégibb időktöl 1867-ig [The History of the Jews in Budapest from the Most Remote Times to 1867] (Budapest: Izraelita Magyar Irodalmi Társulat, 1901), 429. The Jewish emancipation bill was passed by the Lower House but was defeated in the Upper House.

5 János Varga, A Hungarian Quo Vadis: Political Trends and Theories of the Early 1840s (Budapest: Akadémiai Kiadó, 1993), 22-42.

6 Elek Fényes, Magyarország leírása [Description of Hungary], vol. I. (Pest: Beimel, 1847), 25, 32. 
"theocratic regime” prescribing a "caste-like isolation," Jews could all the less be an ethnic group as in contrast to other "races," such as the Slovaks, the Germans or the Romanians, their ethnicity was one whose separateness was elevated by their religion to a religious dogma. According to Kossuth, Jews had to convene a Sanhedrin in order to reform Judaism, so that "they become a separate religious denomination, but, nevertheless, cease to be a separate people."7 The short article-in fact, a long footnote appended to someone else's editorial-written by Kossuth in 1844 had a decisive influence on the Hungarian emancipation debate. It doubtlessly contributed to the growing hostility toward Jewish emancipation. After his remarks, an increasing majority of liberals made their support of emancipation contingent on the reform of Judaism. The bill presented by the national Diet to the king for his assent in 1844 provided only minor improvements in the conditions of the Jews since, as the introductory text explained, the Jews' abrogation of the "obsolete customs" that hampered their social integration had to precede their complete emancipation. ${ }^{8}$ The Diet was finally dissolved without the bill being approved by the king. ${ }^{9}$ If for a different reason-the Hungarians' defeat in the war of independence-the Emancipation Act passed on July 28, 1849 had not come into force either, it was more liberal in that it did grant emancipation to the Jews before a religious reform that the act nevertheless enjoined the Jews to deliberate. ${ }^{10}$

Eighteen years later, in September 1867, Leopold Löw, the leading Reform rabbi of nineteenth-century Hungary, could rightly point out that public opinion had evolved on the issue: "By now, everybody admits that all those who in the forties considered that civil emancipation should be conditioned upon religious reforms were in error. This is now an outdated standpoint." ${ }^{11}$ Indeed, times were ripe for emancipation. Three months later, on December 20 and 23, 1867, the bill on Jewish emancipation passed in the Lower House of the Parliament without any debate,

7 Gábor Fábián, “Zsidó-emancipatió” [Jewish Emancipation], Pesti Hírlap, May 5, 1844, 300.

8 Ferencz Kovács, Az 1843/44-ik évi magyar országgyülési alsó tábla kerületi üléseinek naplója [Records of the District Sessions of the Hungarian Parliament's Lower House in 1843-1844], vol. VI. (Budapest: Franklin-Társulat, 1894), 121-126.

9 Zsigmond Groszmann, A magyar zsidók V. Ferdinánd alatt (1835-1848) [The Hungarian Jews under Ferdinand V. (1835-1848)] (Budapest: Az “Egyenlőség” Könyvkiadóhivatala, 1916), 25.

10 Jenő Zsoldos, ed., 1848-1849 a magyar zsidóság életében [1848-1849 in the Life of Hungarian Jewry], $2^{\text {nd }}$ ed. (Budapest: Múlt és Jövő Kiadó, 1998), 262-264.

11 Lipót Löw, “A magyar zsidók története” [The History of Hungarian Jews], A Hon, September 3,1867 , n. pag. 
and in the Upper House after five short supportive speeches. ${ }^{12}$ The Emancipation Act, which came into effect on December 28, 1867, did not contain any conditions.

Yet, by giving "the Israelite inhabitants of the country" equal civil and political rights with "Christian inhabitants,"13 the law implicitly reasserted the fundamental tenet of the ideology of Jewish emancipation. Jews could be only a religious community, their religious faith was the only thing that separated them from their non-Jewish fellow citizens. Since they supposedly did not have a living language of their own, they could not be a nationality. Of course, it would be once again more precise to say that since emancipation had been granted to Jews in exchange for their endorsement of the Hungarian cause, they could not be recognized as a separate nationality, and thus, could not be recognized as having their own language either. Since most Jews at the time spoke Yiddish, and since a substantial minority among them still did so during the final years of the Dual Monarchy, authorities were forced into adopting creative rhetoric. As the instructions for census-takers in 1910 stated, since "only living languages" could be registered, "the Jewish [i.e. Yiddish] or Hebrew language" could not be taken in account. Therefore, those "persons of Jewish religion" who spoke "German mixed or corrupted by Hebrew, the so-called Jargon," were to be classified as German speakers. Following this tortuous logic, Yiddish speakers were speaking a dead language. ${ }^{14}$

The official definition of the Jews and Judaism remained unchanged until the end of the Dual Monarchy. Hungarians of the Mosaic faith differed from their compatriots only in their religious affiliation. The synagogues, the Jewish communities, and their institutions were the only legitimate spaces for public expressions of Jewishness. Concerning Jews' desirable degree of Magyarization, the political and cultural elite did not really expound on the subject. In this era of homogenizing nationalism, there was no need to do so. Hungarian liberal nationalism certainly recognized Jews' legitimate right to remain faithful to the religion of their fathers. In contrast to Germany, asking for their conversion was politically incorrect. ${ }^{15}$ But otherwise, the self-evident expectation was for the Jews to

12 Képviselóházi napló, 1865-1868, [Records of the Lower House of the Parliament, 1865-1868] vol. VI. (Budapest: Emich Gusztáv, 1868), 257; Förendiházi napló, 1865-1868 [Records of the Upper House of the Parliament, 1865-1868] (Pest: Athenaeum, 1969), 308-311.

13 László Gonda, A zsidóság Magyarországon 1526-1945 [The Jews in Hungary 1526-1945] (Budapest: Századvég Kiadó, 1992), 270.

14 A m. kir. központi statisztikai hivatal munkássága (1871-1911) [Report on the Activities of the Hungarian Royal Office of Statistics, 1871-1911] (Budapest: Pesti Könyvnyomda Részvény-Társaság, 1911), 497.

15 Miklós Konrád, Zsidóságon innen és túl. Zsidók vallásváltása Magyarországon a reformkortól az elsö világháborúig [Within and Beyond Jewishness: Jewish Conversion in Hungary from 
completely identify with Hungarians. To give some excerpts from a parliamentary debate on the Jewish school fund in 1880, they had to become Hungarians not only in "patriotic feelings," "language," "culture," "customs," and "morality," but also in their "thoughts," and "emotions." 16 In 1889, writing for Egyenlöség [Equality], the most widely read Neolog Jewish weekly, an anonymous author who signed a previous article "A true friend of the Jews" reminded the Jews of their duties in the following terms:

Jews must do their best to become externally and internally similar to other Hungarians. They can be Jews by religion, but this must not lend them any specific character. [...] Once again, we draw the attention of the Jews to the fact that in their own interest, they should cautiously refrain from all kinds of distinctiveness and strive with all their energy not to differ in any way from the other habitants of the country, not even in the slightest externals. ${ }^{17}$

Needless to say, when speaking of “other habitants,” he meant Hungarians. As Béla Tóth, one of the most famous liberal publicists of his time, wrote in 1900: "Only Hungarianness has the strength to wipe out all alien features from the innermost being of our Jewish brothers. Because this is the ultimate goal."18 Theoretically, Hungarian liberal nationalism did not tolerate any difference except religion.

So much for the official slogans. Concurrently, however, the liberal political elite often voiced opinions that contradicted, in full or in part, the official dogma. These opinions are all the more remarkable since, with one exception, nobody seemed to notice the contradiction. In a speech to Parliament in 1874, Ferenc Pulszky, a leading Hungarian liberal, explained that unlike the language-based Hungarian nationality, the Jewish "nationality" was defined by "religion" and "blood.” Pulszky saw no problem here; on the contrary, he declared himself to be "a great admirer of the Jewish nationality," indeed a "noble nationality which preserved its own character for millennia." In a seemingly self-contradictory way, he then praised the Jews for assimilating perfectly into the German, English, French, and Hungarian nations. ${ }^{19}$ In this instance, one of the MPs who spoke after Pulszky reminded him that the Jews were not-and should not be-considered

the Age of Reform to World War I] (Budapest: MTA Bölcsészettudományi Kutatóközpont Történettudományi Intézet, 2014), 72-104.

16 Árpád Zeller, A magyar egyházpolitika, 1847-1894 [Hungarian Ecclesiastical Politics, 18471894], vol. II. (Budapest: Boruth. E. Könyvnyomdája, 1894), 1053, 1076, 1096.

17 "Újabb tanács” [Another advice], Egyenlöség, February 10, 1889, 8, 10.

18 Béla Tóth, “Elég-e?” [Is it Enough?], Pesti Hírlap, October 21, 1900, 2-3.

19 Képviselőházi napló, 1872-1875 [Records of the Lower House of the Parliament, 1872-1875], vol. XI. (Buda: Magyar Királyi Államnyomda, 1874), 239-240. 
a nationality. ${ }^{20}$ But no one said a word when Ágoston Trefort, Minister of Religious and Educational Affairs, remarked casually during the same session that "among the Israelite population, as in the case of every ancient people, the népfaj is identical to the religion." 21 Nor did anyone object, not even on the opposition benches, when in 1881 Prime Minister Kálmán Tisza, a convinced liberal, stated incidentally that "the Israelites [...] constitute a race just as much as they constitute a religious denomination." 22 And finally, no one contradicted the MP Géza Mocsáry, when two years later he set out to explain, without assigning any value judgment, that "among the Jews, racial, national, and religious characteristics have been fused into a common and particular type."23

How is this dual discourse to be explained? Certainly, one should keep in mind that terms like "people," "népfaj," "nationality," or "race" had a flexible meaning and were often used by contemporaries in an unconscious way. Even so, the discourse appears to be patently self-contradictory.

As for possible explanations, the first is political. "Those who are with usthey are us," declared the ex-Prime Minister Dezső Bánffy in a conversation with journalists on Jewish issues in 1903. ${ }^{24}$ Aside from strident appeals for complete assimilation, there were two things Jews were definitely expected to do: they had to adopt the Hungarian language as quickly as they could and vocally support the ideal of the Hungarian nation-state. The Jews largely met this expectation. While their linguistic acculturation began on a large scale only in the 1860s, by 1880, the percentage of Jews declaring themselves to be native Hungarian speakers reached $56 \%$, then grew to $77 \%$ in 1910 . In Budapest, it reached by then $90 \%$. Orthodox Jews were less likely to adopt the Hungarian language, but their Hungarian-language press was just as vocal as the Neolog press in asserting Jews' patriotism and insisting on their support for the Hungarian cause in regions populated mainly by Non-Hungarians. ${ }^{25}$ Everything else was secondary. In 1885, while speaking about Jewish immigrants, Kálmán Tisza was interrupted by an antisemitic MP

20 Ibid., 244.

21 Ibid., 231.

22 Képviselóházi napló, 1878-1881 [Records of the Lower House of the Parliament, 1878-1881], vol. XVII. (Budapest: Pesti Könyvnyomda-Részvény-Társaság, 1881), 276.

23 Képviselóházi napló, 1881-1884 [Records of the Lower House of the Parliament, 1881-1884], vol. IX. (Budapest: Pesti Könyvnyomda-Részvény-Társaság, 1883), 168.

24 “Beszélgetés Bánffy Báróval” [Conversation with Baron Bánffy], Jövendő, March 3, 1903, 5.

25 Viador [Dániel Weisz], “A zsidó iskolák” [The Jewish Schools], Zsidó Híradó, July 28, 1892, 1-2; Idem., “Kiközösítve” [Ostracized]. Zsidó Híradó, March 2, 1893, 1-2. Béla Tóth, "Elég-e?” [Is it Enough?], Pesti Hírlap, October 21, 1900, 2-3. 
who shouted “it's not the religion!” The prime minister, who clearly considered this a minor quibble, placidly continued: "Well then, race, if you like."26

A second explanation is related to the perception of the Jews. Regardless of the ideology of emancipation, Hungary's liberal politicians-and Hungarian society as a whole-tended to consider Jews as more than a religious denomination. They certainly thought so at the beginning of the Dualist era, quite understandably, since at that time Hungarian Jewry still remained largely unacculturated. The perception of their otherness was inevitably expressed in terms theoretically inapplicable to Jews. In a book entitled The Nationalities of the Hungarian Empire (1867), Elek Fényes excluded the Jews from the nationalities on the official ground that "they do not have their own living language." Yet, as he did twenty years earlier, he wrote in his book about the characteristics of the Jewish népfaj. ${ }^{27}$ Nine years later, in a book published by the Hungarian Academy of Sciences, Pál Hunfalvy, a pioneer figure of Hungarian historical ethnology, also stressed that Jews were not a nationality, but then included a chapter on the Jewish people, presented alongside Hungarians, Germans, Slavs, Romanians, Armenians, and Gypsies. ${ }^{28}$ In May 1882, calling to order the antisemitic MP Győző Istóczy, the Speaker of Parliament, Tamás Péchy, asked him to watch his words when speaking of an "industrious and hard-working people so large in number."29 Two months later, and once again in reaction to an antisemitic rant by Istóczy, the Vice Speaker Pál Szontagh enjoined him not to forget that "Hungary has 500,000 habitants belonging to this népfaj." 30

By the turn of the century, the acculturation of the majority of Hungarian Jews was an accomplished fact, with the notable exception, however, of the northeastern part of the country where ultra-Orthodox, and notably Hasidic Jews, "maintaned a position of total exclusiveness in regard to outer society, living in a world of their own." 31 While in 1910, as noted earlier, 77\% of Jews declared Hun-

26 Képviselőházi Napló, 1884-1887 [Records of the Lower House of the Parliament, 1881-1884], vol. VI. (Budapest: Pesti Könyvnyomda-Részvény-Társaság, 1885), 390.

27 Elek Fényes, A magyar birodalom nemzetiségei és ezek száma vármegyék és járások szerint [The Nationalities of the Hungarian Empire and their Number by Counties and Districts] (Pest: Eggenberger Ferdinánd M. Akad. Könyvárus, 1867), 17, 30.

28 Pál Hunfalvy, Magyarország ethnographiája [The Ethnography of Hungary] (Budapest: A M. Tud. Akadémia Könyvkiadó-Hivatala, 1876), 419, 518-527.

29 Képviselőházi Napló 1881-1884 [Records of the Lower House of the Parliament, 1881-1884], vol. V. (Budapest: Pesti Könyvnyomda-Részvény-Társaság, 1882), 63.

30 Ibid., 260.

31 Nathaniel Katzburg, "Assimilation in Hungary during the Nineteenth Century: Orthodox Positions," in Jewish Assimilation in Modern Times, ed. Bela Vago (Boulder: Westview Press, 1981), 51. 
garian as their mother tongue or their Umgangssprache, in the four northeastern counties of Bereg, Ung, Máramaros, and Ugocsa, only 35,2\% of the Jews did so. In Máramaros county, the bastion of ultra-Orthodoxy, this proportion fell to seventeen percent. ${ }^{32}$ This probably explains why László Nyegre, an MP of the governing Liberal Party and author of a book (1900) on Máramaros county, classified the Jews without any explanation among the "nationalities" of the region. ${ }^{33}$

In striking contradiction with its official denial of Yiddish language's mere existence, from 1910 to 1912, the Hungarian Office of Statistics included "Jargon" in its tables on the languages of sermons. As the tables show, the number of Jewish "mother communities" (communities authorized to keep birth, marriage, and death registries) where sermons were delivered in Yiddish rose between these two dates from eighty-three to ninety-nine. These communities, all of them Orthodox and most of them probably located in the northeastern part of the country, represented respectively 18 and $21 \%$ of the Hungarian Jewish "mother communities." 34

The perception of the Jews as being something more than a community of faith also explains why Hungarian liberal politicians and intellectuals spoke of the Jewish "race." Although the use of racial terminology increasingly accorded with essentializing, pseudo-scientific theories, even at the end of the nineteenth century, the word "race" was still frequently used as a simple synonym for peoplehood. In liberal political discourse, "Hungarian race" would often refer to those citizens who declared Hungarian to be their mother tongue in national censuses regardless of their ethnic background..$^{35}$ Most non-Jewish Hungarians spoke of the "Jewish race" without any connotation of immutable biological essence. This was certainly the case with Gábor Baross, Minister of Trade and MP of the town of Győr, who declared to the rabbi of the town in 1892: "I deeply respect your reli-

32 Miklós Konrád, “Az Államhatalom és a régió más népességeinek viszonya a zsidósághoz” [The Attitude Towards the Jews of the State Power and Other Populations of the Region], in Zsidók Kárpátalján: Történelem és örökség a dualizmus korától napjainkig [Jews in Carpathian Ruthenia: History and Heritage from the Mid-19th Century to the Present], eds. Viktória Bányai, Csilla Fedinec, and Szonja Ráhel Komoróczy (Budapest: Aposztróf Kiadó, 2013), 107-108.

33 László Nyegre, Máramaros megye [The County of Máramaros] (Budapest: Pesti Könyvnyomda-Részvénytársaság, 1900), 8, 11-12.

34 "Statisztikai táblázatok" [Statistical tables], in Magyarország közoktatásügye az 1910. évben [Hungarian Public Education in the Year 1910] (Budapest: Athenaeum, 1912), 112-113; "Statisztikai táblázatok” [Statistical Tables], in Magyarország közoktatásügye az 1912. évben [Hungarian Public Education in the Year 1912] (Budapest: Athenaeum, 1913), 116-117.

35 See for instance (G), "A magyar állam ereje” [The Strength of the Hungarian State], Pesti Hírlap, April 30, 1882, 1-2; Kornél Ábrányi ifj., Nemzeti ideál [National Ideal], XXIV. (Budapest: Légrády, 1898); Gusztáv Beksics, A magyar politika új alapjai [The New Foundations of Hungarian Politics] (Budapest: Athenaeum, 1899), 57. 
gion, I admire and love your race." ${ }^{36}$ When the most famous Hungarian writer of the $19^{\text {th }}$ century, Mór Jókai glorified in 1898 the participation of the "Hebrew race" in the War of Independence of 1848-1849, he certainly not meant to describe Jews as a biologically fixed group unable to change and become truly Hungarian. He meant exactly the contrary. ${ }^{37}$

Naturally, there is no doubt that the racial perception of Jews was also a result of the Zeitgeist: as elsewhere in Europe in the second half of the nineteenth century, racial theories pervaded scientific and public debates. In a book called Our Homeland and Its People (1889), the statistician and academic Károly Keleti reasserted the principle according to which the Jews were not a nationality because they did not have a living language of their own-the Yiddish, he declared, could not be "seriously" considered a language. But he firmly rejected the view that they were only a religious community, since, as he wrote, "besides their denomination, or rather, under its influence and as a consequence of it, Israelites constitute a separate race and, indeed, one of the purest surviving races." For Keleti, the term had no negative connotations whatsoever, on the contrary, he had only praise for Jewish "racial" qualities. ${ }^{38}$

Because of the contradictions between political principles and socio-cultural perceptions, the discourse of the Hungarian political and cultural elite remained polyphonic at the time of the Dual Monarchy. It considered at least one potential component of Jewish identity, the idea of a Jewish nation, to be fully illegitimate, but otherwise it left much room for Jewish self-definition.

\section{Jewish self-definitions}

Similar to the Hungarian liberal discourse, the Jewish discourse also proved to be self-contradictory, divided as it was between the need to comply with external expectations and the desire to foster Jewish identity.

36 József Kemény, Vázlatok a györi zsidóság történetéből [Sketches from the History of the Jews of Győr] (Györ: n. p., 1930), 91.

37 Mór Jókai: “Előszó” [Foreword], in Béla Bernstein, Az 1848/49-iki magyar szabadságharcz és a zsidók [The Hungarian War of Liberation of 1848-49 and the Jews] (Budapest: Izraelita Magyar Irodalmi Társulat, 1898), VII-VIII.

38 Károly Keleti, Hazánk és népe: A közgazdaság és társadalmi statistika szempontjából [Our Homeland and its People: From an Economic and Social Statistical Viewpoint] (Budapest: Ráth Mór, 1889), 400-402. 
In 1841, the Jewish communities of Pest and Óbuda complained to Pest county that some newspapers were seeking to "discredit the Jewish nation in the eyes of public opinion." The county began its response by stating that "it does not wish to regard Jews as a separate nation, but rather as a separate, until now only tolerated religious denomination." ${ }^{39}$ Clearly, "does not wish" was a euphemism, and there is no doubt that the self-definitions put forward publicly in the $1840 \mathrm{~s}$ by rabbis and Jewish intellectuals fighting for emancipation were primarily dictated by political considerations. They were reactions to expectations and accusations coming from without, political responses intended to counter arguments advanced against the emancipation of the Jews. Under the circumstances, this meant on the one hand denying the existence of the Jewish nation, Jewish nationality, and Yiddish as an authentic, or even simply a living language, and, on the other hand, emphasizing universalized messianism, the exclusively religious nature of Judaism, and the ability of Jews to assimilate into Hungarian society. ${ }^{40}$

In 1844, reacting to a pamphleteer opposed to the emancipation of the Jews on the grounds that they still conceived of themselves as a separate nation waiting for the Messiah to lead them back to Zion, Leopold Löw emphasized: “Through their spokesmen, Jews have declared and repeated a hundred times that they do not form a nation, but rather a community of faith, and that they are absorbed into the nationality of the nations among which they live." ${ }^{41}$ In his response to Kossuth's article, Löw argued that Jews could only be called a people "in terms of their common origins," to which there could be no objection. However, in a

39 "Vidéki levéltárcza" [Letter from the Countryside] Pesti Hírlap, May 1, 1841, 288.

40 Leopold Löv [sic], “Még néhány szó ‘a 'zsidók” erkölcstelensége’ s a 'zsidók’ polgárosítása fölött” [A Few More Words on "the Immorality of the Jews" and on Jewish Civil Rights], Pesti Hírlap, July 25, 1844, 505-506; Jogfi, “Mozaiták ügyében” [Concerning Mosaites], Pesti Hírlap, May 2, 1845, 289-290; Márton Diósy, “A honi izraeliták között magyar nyelvet terjesztő pesti egylet” [The Pest Association for the Diffusion of the Hungarian Language among the Jews of the Country], in Első magyar zsidó naptár és évkönyv 1848-ik szököévre [First Hungarian-Jewish Calendar and Yearbook for the Leap Year 1848] (Pest: Landerer és Heckenast, 1848), 86-88; “A honi izraeliták belügyeit kezelő választmány körlevele" [Circular of the Committee Managing the Internal Affairs of the Country's Jews], in 1848-1849 a magyar zsidóság életében [1848-1849 in the Life of Hungarian Jews], ed. Jenő Zsoldos, 2d ed. (Budapest: Múlt és Jövő, 1998), 62-64; Lipót Hartmán, Magyar zsidó, vagy: zsidó magyar? [Hungarian Jew or Jewish Hungarian?] (Pécs: Lyceumi nyomda, 1848).

41 Dr. J. G, Némelly Igénytelen Nézetek, vallásilag véve, A' magyarhoni zsidók' meghonosítása' 's a' magyar nemzetteli egybeolvadása ügyében [A Few Modest Opinions, from a Religious Point of View, Concerning the Civil Rights of the Jews and their Amalgamation with the Hungarian Nation] (Kőszeg: Reichard Károly, 1843); Leopold Löw, “Zur Emancipationsfrage” (1844), in Gesammelte Schriften, ed. Immanuel Löw (Szegedin: Verlag von Ludwig Engel, 1898), IV, 358. 
political sense, the Jews-who lacked a homeland, a language, and "civil laws"did not constitute a nation, or a nationality. In fact, since they lacked the usual attributes of peoplehood, such as their own songs, dances and ways of dressing, they were not even really a "separate people."42

At the time of neo-absolutism, the writings of the nascent Neolog intelligentsia continued to serve primarily political ends-that is, the emancipation of the Jews. When, in 1861, a Jewish primary school teacher in Sátoraljaújhely spoke carelessly in the weekly Magyar Izraelita [Hungarian Israelite] about the Jews' duty to maintain their "national selves," the editor did not fail to correct him, reminding his readers in a footnote of the official position: "That's wrong! Jews are not a nation, but only a denomination!" 43 By this time, though, the main message was not so much the negation of Jewish nationhood, but rather the assertion that Jews were not a nationality and did not have any ambition to be considered as one. ${ }^{44}$ Unlike other groups, stressed Magyar Izraelita in 1861, Jews had never "bothered" Hungarians with any "nationality claim.” The message was all the more clear when the author concluded by remarking that Jews could thus rightly expect the Hungarian nation of which they wished to become members "to fold [them] in his arms." 45

Concerning Jewish ethnicity, there seems to have been some difference of opinion. While Ignác Hirschler, the president of the Jewish community of Pest, repeated that "regarding their nationality and language," Jews living in Hungary could be no one else than Hungarians, he also stated that they were indeed a népfaj and had to cherish the "memories of [their] racial origins."46 Others categorically denied that Jews formed an ethnic group, ${ }^{47}$ or admitted its existence, but emphasized that their ethnic distinctiveness would soon vanish, all the more

42 Leopold Löv [sic], “Nyílt levél a’ zsidó-emancipatio ügyében” [Open Letter Concerning Jewish Emancipation], Pesti Hírlap, June 2, 1844, 375.

43 “Iskola-ügy” [Educational affair], Magyar Izraelita, February 14, 1861, 53.

44 Lipót Rokonstein, A magyar izraelita 1860-ik évben [The Hungarian Israelite in the Year 1860] (Pest: Wodianer F., 1860), 10-11; Lipót Löw, “A magyar nemzetiség és a zsidók” [Hungarian Nationality and the Jews], in Történelmi és vallástudományi értekezések [Historical and Theological Studies], 4 (Szeged: Burger Zsigmond, 1861); Rokonyi, “Összeolvadásunk kellékei” [The Materials of Our Amalgamation], Magyar Izraelita, January 17, 1861, 17-20; Egy hitrokon (anonymous), A zsidók reformátiója [The Reform of the Jews] (Pest: Heckenast Gusztáv, 1867), 8.

45 (Fmt.), "Hazafiasságunk tüzpróbája” [The Final Test of Our Patriotism], Magyar Izraelita, July 26, $1861,247$.

46 Ignác Hirschler, Emlékbeszéd néhai Kern Jakab felett [Speech in Memory of the Late Jakab Kern] (Pest: Izraelita-Magyar-Egylet, 1866), 26.

47 Mór Mezei, “A határozati javaslat és a zsidó kérdés” [The Resolution Proposal and the Jewish Question], Magyar Izraelita, July 19, 1861, supplement, n. pag. 
rapidly if Hungarians granted them equal rights. As Magyar Izraelita wrote in 1862: "Everywhere that a nation has accepted them as its equal members, the Jews have voluntarily renounced their so-called ethnic characteristics and have merged perfectly into the political nation!" 48 The writings of Neolog intellectuals clearly indicate that in this period they were still more concerned with the political future of the Jews than with the future of their Jewish identity. Since the mass acculturation and secularization of Hungarian Jews was only just beginning, this is hardly surprising.

In the Dualist era, the official Neolog self-definition did not change-it could not change. As Leopold Löw wrote in September 1867, four months before Jews were actually given equal civil rights, "With the Emancipation Act, a new era begins for Hungarian Jewry. Having politically and socially amalgamated with the nation, Hungarian Jewry's history is to be reduced from now on to church history." 49 In the synagogue, the parliament, in books and articles in the Jewish and non-Jewish press, Neolog Jews repeated thousands of times that Judaism was a religion and that Jews were Hungarians of Jewish faith. They were neither a nation, nor a nationality, nothing other than a religious community. Neolog intellectuals emphasized the official dogma particularly during periods when this was perceived to be a political necessity: in the first half of the 1880s, at the time of the Tiszaeszlár blood libel affair, and then in the mid-1890s. In these closing years of the nineteenth century, the enthusiasm raised by the "reception law," which granted the Jewish denomination equal status with Catholic and Protestant churches, and the simultaneous concern over the sudden rise of antisemitism and the emergence of political Zionism, generated a flurry of politically correct assertions of Jewish self-definition..$^{50}$

By this time, the principles of the emancipation dogma had been supplemented by one final argument: Jews had become Hungarians, their Magyarization was a fait accompli. Since Jews did not exist as such outside the synagogue,

48 B. M, "Mi a zsidó az államban?” [What is Jewish in the State?], Magyar Izraelita, August 22, 1862, 279.

49 Lipót Löw, “A magyar zsidók története” [The History of Hungarian Jews], A Hon, September 3, 1867, n. pag.

50 See, for instance, Lajos Palágyi, “A zsidó nemzet” [The Jewish Nation], Egyenlőség, March 3, 1893, supplement, 1; Ignácz Weisz, A zsidók és a nemzetiségek [Jews and the Nationalities] (Brassó: "Brassó” könyvnyomdája, 1894), 10-11; Miksa Pollák, Izraelita ultramontanizmus [Israelite Ultramontanism], Pesti Hírlap, October 30, 1895, 3-4; “Zsidó nemzetiség” [Jewish Nationality], Egyenlőség, May 23, 1897, supplement, 2-3; László Seress, “Asszimiláczió” [Assimilation], Egyenlöség, July 4, 1897, 4-5; [Lajos Blau,] “A czionizmus” [Zionism], Magyar Zsidó Szemle 14 (1897): 289-292. 
they could not be subjected to any criticism either. Nor could they become Zionists, for their sense of belonging to the Hungarian nation was now an ineradicable, vital element of their identity. As Lajos Blau, a teacher (and later rector) at the Budapest Rabbinical Seminary [Országos Rabbiképző Intézet] and editor of the periodical Magyar Zsidó Szemle [Hungarian Jewish Review], stated in 1896: "Hungarian Israel has completely merged into the body of the Hungarian nation. It has become Hungarian, just like any other denomination, and does not wish to be anything else than a religious body. And it can not be anything else, for it is completely Hungarian in its language and thinking." ${ }^{51}$ In their official pronouncements, so to speak, Neolog intellectuals could not say anything else. Nor could they teach anything else. In 1909, the Jewish community of Pest published a new religious textbook for first graders. In the book's "Introductory Concepts," one reads: "We are Hungarians. Hungary is our dear homeland and Hungarian is our mother tongue. [...] Not all people worship God in the same way. [...] Hungarians too are of various religions. Our religion is the Israelite, or, in other words, the Jewish religion. We are therefore Hungarians Israelites, that is, Hungarians of Jewish religion." ${ }^{52}$

From the 1890s onwards, however, Neolog intellectuals, while constantly repeating the tenets of official dogma, increasingly addressed ideas and concepts that diverged from it. What was new was not so much the use of terms theoretically inapplicable to Jews, as rather its deliberateness, the conscious agenda behind their use. These alternative self-definitions stemmed from the Neolog intellectuals' desire to counter what they perceived to be a dramatic spread of indifference to all matters Jewish, a dramatic alienation of the acculturated middle class from its religion and community. ${ }^{53}$ Given their secularization, the concepts capable of sustaining and reinforcing their sense of Jewish belonging had to go beyond the religious sphere. This gave rise to a language incompatible with the official dogma, but which Neolog intellectuals could, in fact, use without great political risk.

The reconceptualization had its limits. Concerning their own time, Neolog intellectuals kept on denying Jewish national aspirations, and the national component of Jewish identity. They could not go that far-and they certainly did not

51 [Lajos Blau,] “Ezer év” [A Thousand Years], Magyar Zsidó Szemle 13 (1896): 194.

52 Ignácz Kondor, Képes héber olvasókönyv: Az elemi iskolák I. osztálya számára [Illustrated Hebrew Primer for the First Grade of Elementary Schools] (Budapest: Lampel R. Könyvkereskedése, 1909), 7-8.

53 Miklós Konrád, “A neológ zsidóság útkeresése a századfordulón” [Neolog Jewry’s Search for New Paths at the Turn of the Century], Századok 139 (2005): 1335-1369. 
want to either. Neolog intellectuals spoke of a Jewish nation only to deny its existence, particularly after the appearance of Zionism. As Miksa Szabolcsi, the editor-in-chief of Egyenlöség wrote in 1898: "We simply do not know of any Jewish national feeling among Hungarian Jews. There can be only one national feeling in someone's heart. The one felt by Jews in this country is Hungarian. The Jew can have a racial feeling, a religious feeling, but never a national one."54 There was however a spectacular change in the interpretation of the past. In 1898, A Jövö [The Future], a weekly that expressed the views of a younger generation of Neolog intellectuals, mostly rabbis, sharply criticized the idea of the mission of the Jews. The weekly denounced those "modern theologians" who sought to interpret the past "according to the tastes of today's world," then bluntly declared: “The idea that ancient Israel followed religious aspirations in everything is a mistake. In fact, almost the reverse is true. I could quote hundreds of passages of the Holy Scriptures which demonstrate that religion itself served national objectives." 55

Neolog Jews had greater political latitude in using ethnic self-definitions. This is not to say that this was not a sensitive issue. The clearest sign that ethnic self-definition was not really compatible with the dogma of emancipation, is the fact that some Neolog Jews spared no effort in trying to prove that there was nothing such as a Jewish people. As Lajos Blau argued in 1890: "Even before the end of its national existence, Israel did not constitute a people in the common sense of the word, but rather an ethical community-a denomination." ${ }^{56}$ Yet, there was also a clear departure from the politically less controversial definition of Jewish ethnicity; that is, the recognition of Jews' common origins. What we observe, instead, is a conscious effort to re-ethnicize Jewish self-conception. Alongside Jewish intellectual history, Neolog rabbis increasingly emphasized the glorious-and thus hopefully inspiring-history of the Jewish people. As the Óbuda rabbi Illés Adler declared to Sándor Goldberger von Buda at his bar mitzvah in 1898:

You've doubtless studied our people's glorious history, and you shall learn more about it. [...] If you want your faith to get stronger and deeper, if you want some shining role models, look back to the past. Look at the forefathers, look to Moses, to King David, see Solomon, the wise king whose name you bear, or think about the loyal Mordechai and Esther, who saved her people. [...] Your young heart will whisper to you: they were all Jews, and I too am a Jew, and I am proud to be a Jew. Oh my child, you might well do it! Confess proudly that you are

54 Miksa Szabolcsi, “Igazolásul” [As a Matter of Justification], Egyenlöség, January 16, 1898, 12. 55 - s - r., “Mit tanítsunk?” [What Should We Teach?], A Jövö, April 22, 1898, 8.

56 Lajos Blau, Izraél kiválasztása [The Election of Israel] (Budapest: Athenaeum, 1890), 17. 
a Jew! Learn from your gold-hearted father how to be a good and worthy man, a good and worthy Jew, to feel and act as a Jew. ${ }^{57}$

Besides the re-ethnicization of the Jewish past, Neolog intellectuals began to write about Jewish néplélek [folk-soul], they praised the virtues of the Jewish "people", its outstanding inclination for charity, learning, and-above all-its unique contribution to human culture. Naturally, this notion also served apologetic purposes, but one should not neglect its role in efforts to strengthen the identity of secularized and acculturated Jews..$^{58}$ As the poet Lajos Palágyi declared in 1889, "the Jewish people is the most prominent kulturnép [Kulturvolk] in the world; therefore, to be ashamed of belonging to it is not only dishonorable, but also stupid. There is no doubt that Jews can offer themselves as a model to other people." ${ }^{59}$ In a seemingly paradoxical way, the emphasis on Jewish ethnicity also served the purpose of bringing middle-class Jews back to their religion-a religion now presented as symbiotically combined with peoplehood. "What is it that makes a Jew a Jew?,” asked in 1912 the Pécs rabbi Ármin Perls in his Shavuot Sermon. "It's not just blood, origin, historical consciousness, but nor is it only the idea of God, the community of faith. Rather, what makes Judaism, is an intimate, warm, lively and harmonious fusion of the two into a complete whole." ${ }^{60}$ There's no need to say how unimaginable it would have been for Leopold Löw to write such lines in his response to Lajos Kossuth.

Alongside efforts to strengthen Jewish identity by enlarging its base within the limits of a religious self-definition, some intellectuals also began to write about Jewish ethnicity in a secular sense. In the introduction to a volume of poems by the Yiddish poet Morris Rosenfeld published in 1908, the translator and Buda rabbi Arnold Kiss wrote that Rosenfeld, who owed his popularity to his ability to express the suffering of thousands and thousands of Jews, was to be considered "a poet of the people," of all those Yiddish speakers around the world whose language was the expression of Jewish népgéniusz [ethnic

57 Illés Adler, Bârmicvó beszéd [Bar Mitzvah Sermon] (Budapest: Bichler I. Könyvnyomdája, n. d. [1898]), 4-6.

58 On the notion of "Jewish contribution" in modern Jewish thinking, see The Jewish Contribution to Civilization: Reassessing an Idea, eds. Jeremy Cohen and Richard I. Cohen (Oxford: Littman Library of Jewish Civilization, 2008).

59 Lajos Palágyi, “Zsidók a társaságban” [Jews in Society], Egyenlöség, November 17, 1889, 8. 60 Ármin Perls, "Nemzet és felekezet: Sabuóti beszéd" [Nation and Denomination: Sermon for Shavuot], in Szónoklatok [Speeches] (Pécs: Pécsi Irodalmi és Könyvnyomdai R.-T., n. d. [1912]), IV, 21, 23. 
genius]. ${ }^{61}$ In two complementary articles published in 1902 and 1911, Bernát Alexander, the most famous Hungarian philosopher of his time, turned the integrationist theory of the Jewish contribution to European civilization into an argument for dissimilation. Although he praised the Jews' wholehearted acculturation, he also made a claim for the survival of the "Jewish spirit," and the Jewish néplélek. "Ethnic amalgamation" was "not desirable." The best way for Jews to contribute to Hungarian culture was to remain as they were-a separate ethnic group with its intrinsic qualities. ${ }^{62}$

This idea of intrinsic qualities brings us to the appearance of racial language in Jewish writings, of a racial essentialist self-perception of Jewishness that went far beyond the notion of ethnicity. As we have seen, liberal politicians themselves spoke of the Jewish race, and they did so in a harmless, innocent manner. Racial science was the fashion of the day, but it was not necessarily tantamount to racism. As recent historiography, following George Mosse, ${ }^{63}$ had pointed out: "There were many non-Jewish social scientists and thinkers who saw in the Jews a healthy, even superior, people-a racial or eugenic model for contemporary Christians." ${ }^{44}$ Nevertheless, and quite understandably, racial determinism seemed dangerous to Neolog Jewish intellectuals who asserted the ability of their coreligionists to change and become Hungarians. Moreover, since the idea that men were created unequal was encoded in racial thinking, the threat of Jews being proclaimed racially inferior and harmful was always lurking. And certainly that was what modern pseudo-scientific antisemitism did.

Consequently, some Neolog intellectuals denied the existence of the Jewish race, of the existence or pure races, or the existence of racially pure nations, ${ }^{65}$

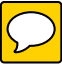

61 Arnold Kiss, "Előszó” [Foreword], in Morris Rosenfeld Költeményei (Gettódalok) [The Poems of Morris Rosenfeld (Ghetto Songs)] (Budapest: Deutsch Zsigmond és társa, 1908), 6, 15.

62 Bernát Alexander, "Zsidóság és magyarság” [Jewishness and Hungarianness], in Almanach: Izraelita Családi Naptár 5663 [Yearbook: Israelite Family Calendar 5663], eds. Károly Ötvös and Zsigmond Dőri (Budapest: Márkus Samu Könyvnyomdája, 1902), 57-58.; Idem., "Zsidó problémák” [Jewish Problems], in Magyar zsidó almanach [Hungarian Jewish Yearbook], ed. Patai József (Budapest: A Magyar Zsidó Almanach Szerkesztősége és Kiadóvállalata, 1911), 188-189.

63 George L. Mosse, Toward the Final Solution: A History of European Racism (New York: Howard Fertig, 1978), 77-93.

64 Mitchell B. Hart, "Jews and Race: An Introductory Essay," in Jews \& Race: Writings on Identity \& Difference, 1880-1940, ed. Idem. (Waltham, Mass.: Brandeis University Press, 2011), XXIII.

65 M. S., "Zsidó magyarok" [Jewish Hungarians], Egyenlőség, December 16, 1883, 2-4; Ernő Salgó, “A faj kérdése” [The Question of Race], Egyenlöség, March 27, 1896, second supplement, 7-8; Béla Lázár, “Faj és Vallás” [Race and Religion], Egyenlőség, January 17, 1897, 4-5; Ignác Peisner, “A zsidó nép faji jellege” [The Racial Character of the Jewish People], in Évkönyv 1907 [Yearbook, 1907], ed. József Bánóczi (Budapest: Izraelita Magyar Irodalmi Társulat 1907), 273-278; 
while others pointed out the potentially fatal implications of racial theories and warned their coreligionists that racial labeling was the most dangerous weapon in the hands of their enemies. ${ }^{66}$ Even so, from the 1890 s onwards, Neolog intellectuals increasingly praised Jewish racial qualities. ${ }^{67}$ The most dangerous component of racial theories, that is the essentialist view of human races, was also the one that proved to be irresistibly seducing. Since Jewish identity seemed battered by modernity, what mattered most was to instill in the secularized Jewish bourgeoisie a feeling of pride in being Jewish. The most effective way to achieve this was to proclaim the essential-eternal and unquestionable-excellence of the Jews. Given the cultural vocabulary at their disposal, this was expressed in racial terms. ${ }^{68}$

Since the target audience was the educated middle class, the central idea revolved around culture. As Menyhért Palágyi, a noted philosopher and literary historian, wrote in 1891:

No race more than the Jews has a stronger inclination towards culture. I do not know how it happened, let it be enough to say that this cultural thirst has run in the Jew's blood and

Ernő Mezei, “Faj, nemzet vagy vallás” [Race, Nation, or Religion], Egyenlőség, February 21, 1909, supplement, 1-3.

66 Menyhért Palágyi, “A 'race” [The "Race”], Egyenlőség, March 20, 1891, supplement, 3; Tamás Kóbor, “Czigányok és zsidók” [Gypsies and Jews], Egyenlőség, October 28, 1900, 1-2; [Lajos Blau], "Faj és nemzet a történelem világításában” [Race and Nation in Light of History], Magyar Zsidó Szemle 20 (1903): 1-5; Lajos Stein, “A fajprobléma és a zsidóság” [The Race Problem and the Jews], in Évkönyv [Yearbook, 1911], ed. József Bánóczi (Budapest: Izraelita Magyar Irodalmi Társulat, 1911), 276-307; “Fajkongresszus” [Race Congress], Magyar-Zsidó Szemle 28 (1911): 241-242.

67 Samu Haber, “Tanév elején” [At the Beginning of the School Year], Egyenlöség, September 6, 1895, 6.; “Az Izraelita Magyar Irodalmi Társulat közgyülése” [The General Assembly of the Hungarian Israelite Literary Association], Magyar Zsidó Szemle 20 (1903): 119; Armand Kőszegi, "A XX-ik évszázad humanizmusa“ [The Humanism of the Twentieth Century], Szombati Újság, December 29, 1905, 2-3; Béla Bernstein, "Az egyetemes vallásoktatási tanterv” [The Universal Curriculum of Religious Instruction], Magyar-Zsidó Szemle, 23 (1906): 83; Sándor Fleischmann, “Fiaim, csak énekeljetek!” [My Sons, Just Sing!], Egyenlőség, January 11, 1914, 1-2.

68 On the Jewish appropriation of racial language, see See John M Efron, Defenders of the Race: Jewish Doctors and Race Science in Fin-de-Siècle Europe (New Haven and London: Yale University Press, 1994); Mitchell B Hart, Social Science and the Politics of Modern Jewish Identity (Stanford: Stanford University Press, 2000); Todd M Endelman, "Anglo-Jewish Scientists and the Science of Race,” Jewish Social Studies 11 (2004): 52-92; Lisa Leff, “Self-Definition and Self-Defense: Jewish Racial Identity in Nineteenth-Century France,” Jewish History 19 (2005): 7-28; Yfaat Weiss, “Identity and Essentialism: Race, Racism, and the Jews at the Fin de Siècle," in German History from the Margins, eds. Neil Gregor, Nils Roemer, and Mark Roseman (Bloomington and Indianapolis: Indiana University Press, 2006), 49-68. 
developed into an overpowering racial passion. [...] Among other races, the inclination towards culture seems to be only some kind of inoculated desire, but in the Jew, it is an elementary passion that springs forth from the roots of his being. ${ }^{69}$

This inclination naturally led to outstanding cultural achievements. As Gyula Weiszburg, one of the rabbis of the Pest Jewish community and its general secretary explained in a lecture delivered in 1911 at the National Hungarian Israelite Cultural Association [Országos Magyar Izraelita Közmüvelődési Egyesület] founded two years earlier, the antisemites were angered by the fact that "in the vast field of intellectual life, they constantly encounter the works of Jewish genius.” And indeed:

With maybe the exception of its most recent development, that is science, the whole culture is so full of Jewish elements that if we were to remove them from its organism, then only a wreck would be left. [...] Ladies and gentlemen! Racial superciliousness is despicable, racial pride is only inspiring. We believe that our race had a great, a giant impact on culture in past times, and we are full of expectations as to its achievements in the future. ${ }^{70}$

Such glorification led sometimes to unambiguous, and generalising pronouncements of Jewish racial superiority. As Egyenlöség noted in 1902: "With a culture going back more than three thousand years and with the inheritance of this culture, the Jew clearly stands above all other races." ${ }^{\prime 1}$

\section{Conclusion}

The self-contradictory discourse of Hungarian liberal nationalism allowed Neolog Jewish intellectuals to offer definitions of Jewishness that were theoretically contradicting their official ones. Neolog Jewish intellectuals made use of this opportunity. Throughout the dualist period, their self-definitions partly served political aims. They were reactions to external expectations and demands. However, from the 1890s onwards, they stemmed more and more from an inner search, from the Neolog intellectuals' efforts to preserve or strengthen the attachments of

69 Menyhért Palágyi, “A zsidó nő a közmüvelődésben” [The Jewish Woman in Public Culture], Egyenlöség, October 2, 1891, supplement, 4.

70 Gyula Weiszburg, "A zsidó faj kulturértéke” [The Cultural Value of the Jewish Race], in Cultur-Almanach 1911-12 [Cultural Yearbook 1911-12], ed. Simon Hevesi (Budapest: Országos Magy. Izraelita Közmüvelődési Egyesület, 1912), 10, 15.

71 Br. J, “A zsidóság és a társadalom” [Jews and Society], Egyenlőség, August 3, 1902, 3. 
the acculturated and secularized middle class to anything that was Jewish. If we take into account that these efforts were developed at a time when increasingly intolerant Hungarian nationalism considered the (previously accepted) cultural autonomy of the nationalities unacceptable, it appears that by the end of the nineteenth century, and in contrast with earlier decades, Neolog intellectuals were more concerned with consolidating the sense of belonging of the acculturated Jewish middle class than with offering to their hypothetical non-Jewish audience a politically correct definition of Jewishness. They were more concerned with the identity of modern Hungarian Jewry than with their integration into Hungarian society, an integration which they thought was about to be accomplished in the first half of the 1890s, and in which they believed less and less from the beginning of the 1900s. Whether their efforts were ultimately successful is another story. 


\section{DE GRUYTER}

OLDENBOURG

Tamás Turán,

Carsten Wilke (Eds.)

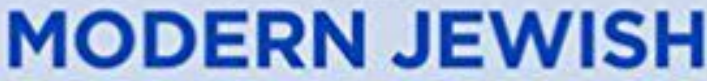

SCHOLARSHIP IN

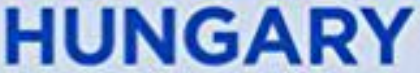

THE 'SCIENCE OF JUDAISM' BETWEEN EAST AND WEST

\section{ItA moses \\ MENDFESOHN \\ ZENTRLN}

EUROPEAN-JEWISH STUDIES CONTRIBUTIONS

\section{$\frac{\text { of }}{\mathrm{G}}$}

